\title{
PENGEMBANGAN PERMAINAN QUESTION CARD SEBAGAI MEDIA PEMBELAJARAN UNTUK MENINGKATKAN BERPIKIR KRITIS SISWA
}

\author{
Nurul Lailia \\ Universitas Negeri Surabaya \\ nurullailia108@gmail.com
}

\begin{abstract}
Abstrak: Penelitian ini bertujuan untuk menganalisis 1) pengembangan Permainan Question Card sebagai media pembelajaran untuk meningkatkan keterampilan berpikir kritis siswa, 2) efektivitas Permainan Question Card pada sebagai media pembelajaran untuk meningkatkan keterampilan berpikir kritis siswa.Penelitian ini dilakukan di kelas X IPS 1 SMAN 1 Kota Mojokerto dengan 20 siswa sebagai subjek penelitian. Jenis penelitian yang digunakan adalah penelitian pengembangan (research and development) dengan model pengembangan ADDIE yang terdiri dari lima tahap, yaitu Analysis, Design, Development, Implementation, dan Evaluation. Desain ujicoba penelitian ini menggunakan desain Pre-Experimental bentuk One Grup Pretest-Posttest. Jenis data dalam penelitian ini meliputi data kualitatif dan kuantitatif, dengan instrumen pengumpulan data berupa lembar telaah dan lembar validasi. Dari hasil penelitian ini, menunjukkan bahwa presentase yang didapat dari ahli evaluasi adalah $93 \%$ dengan kriteria sangat layak dan ahli media 88,86\% dengan kriteria sangat layak. Hasil efektivitas Permainan Question Card yang diujicobakan secara terbatas menunjukkan peningkatan keterampilan berpikir kritis peserta didik melalui uji $\mathrm{N}$-gain dengan nilai rata-rata sebesar 0,6 dengan kriteria sedang.
\end{abstract}

Kata kunci: Permainan Question Card, Media Pembelajaran, Berpikir Kritis

\section{DEVELOPMENT OF QUESTION CARD GAMES AS A LEARNING MEDIA TO IMPROVE STUDENT CRITICAL THINKING}

\begin{abstract}
The purpose of the research is to analyze 1) the development of the Question Card Game as learning media to increase student's critical thinking, 2) the effectiveness of the Question Card Game as learning media to increase student's critical thinking. This study is conducted in class X Social 1 of State Senior High School 1 of Mojokerto City with 20 students as subjects research. The type of research is research and development with ADDIE development model that consists of five steps, namely Analysis, Design, Development, Implementation, and Evaluation. The trial design of this research is the Pre-Experimental design One Group Pretest-Posttest type. The type of data in this research is qualitative and quantitative data with data collection instruments in the form of study sheets and validation sheets. They show that the percentage received from the evaluation expert is $93 \%$ with the criteria very feasible and media expert is $88,86 \%$ with criteria very feasible. The result of the effectiveness of the Question Card Game as learning media showed an increase in student's critical thinking through the $\mathrm{N}$-gain test with an average value of 0,6 with criteria medium.
\end{abstract}

Keywords: Question Card Game, Learning Media, Critical Thinking

\section{PENDAHULUAN}

Dengan seiring berkembangnya zaman, pendidikan mempunyai peranan penting dalam kehidupan manusia. Setiap zaman, pasti akan terjadi perubahan yang mengarah pada kemajuan pendidikan yang makin baik dan manusia yang berpendidikan akan berkembang kearah yang lebih baik (Sanjaya, Wina. 2008: 255). Ditambah lagi, semakin banyak berita yang tidak bisa dipertanggungjawabkan dan menimbulkan provokasi sehingga membangun bersikap kritis dalam proses pendidikan sangat diperlukan (Zaki, Faiz. 2018). Untuk itu dalam dunia pendidikan diperlukan adanya inovasi agar berpikir kritis mahasiswa semakin meningkat. Hal ini perlu 
dilakukan agar kualitas pendidikan tidak hanya menekankan pada teori, tetapi juga dapat diarahkan pada hal yang bersifat praktis.

Pendidikan di Indonesia menekankan siswa sebagai manusia yang memiliki potensi untuk belajar dan berkembang sesuai kebutuhan zaman. Menurut Undang-Undang Nomor 20 Tahun 2003 Tentang Sistem Pendidikan Pasal 1 ayat 1 menyatakan bahwa: Pendidikan adalah usaha sadar dan terencana untuk mewujudkan suasana belajar dan proses pembelajaran agar peserta didik secara aktif mengembangkan potensi dirinya untuk memiliki kekuatan spiritual keagamaan, pengendalian diri, kepribadian, kecerdasan, akhlak mulia, serta ketrampilan yang diperlukan dirinya, masyarakat, bangsa, dan Negara (Depdiknas. 2003)

Kurikulum pendidikan yang sedang dijalankan di Indonesia saat ini adalah kurikulum 2013. Kurikulum tersebut dipandang dapat mengakomodasi tuntutan zaman abad ke 20 ini. Pada kurikulum 2013 diharuskan untuk mengembangkan sikap spiritual dan sosial, pengetahuan, dan keterampilan. Dalam ranah pengetahuan, kurikulum 2013 dikembangkan dengan penyempurnaan penguatan pola pembelajaran kritis. Berpikir kritis tidak didapatkan dari warisan genetik orangtua maupun tanpa adanya proses pembelajaran, namun didapatkan dari berlatih dengan memecahkan permasalahan yang ada (Arends, R. 2008: 76).

Berdasarkan hasil observasi yang dilakukan di kelas X IPS 1 SMA Negeri 1 Kota Mojokerto maka diketahui fenomena bahwa masih rendahnya keterampilan berpikir kritis siswa. Fenomena ini dibuktikan dengan banyaknya siswa yang memberikan jawaban salah pada soal berpikir kritis yang telah diberikan selama pembelajaran berlangsung. Dimana hal ini kurang sesuai dengan kurikulum 2013 yang menuntut siswa untuk mengembangkan pola pikir pembelajarannya untuk pengembangan berpikir kritis. Hal ini juga diperkuat dengan informasi dari guru mata pelajaran ekonomi kelas X IPS 1 SMA Negeri 1 Kota Mojokerto yang menyatakan bahwa tingkat keterampilan berpikir kritis siswa masih rendah. Dalam hal ini Kompetensi Dasar (KD) yang akan dipilih yaitu KD 3.2 Menganalisis masalah ekonomi dan cara mengatasinya. KD tersebut dipilih karena pada $\mathrm{KD}$ ini memuat materi yang berdekatan dengan kehidupan siswa sehingga akan memudahkan siswa dalam membiasakan mengerjakan soal berpikir kritis. Serta KD tersebut menuntut siswa sampai dengan tahap analisis. Apabila tidak menggunakan media pembalajaran yang tepat, tentu akan sulit mencapai $\mathrm{KD}$ tersebut.

Berdasarkan fenomena yang terjadi di atas maka saat pembelajaran berlangsung guru dapat menggunakan media sebagai alat bantu untuk menciptakan tujuan pembelajaran yang diinginkan. Media yang dikemas dengan baik akan merangsang siswa untuk menerapkan sendiri ide yang mereka miliki dan mendorong siswa untuk menggunakan strategi mereka sendiri untuk belajar (Arsyad. 2013: 15). Media permainan merupakan alat bantu yang tepat digunakan dalam pembelajaran karena melibatkan semua siswa sehingga membuat pembelajaran berpusat pada siswa, menumbuhkan suasana kreatif dan pembelajaran yang menyenangkan, serta mengefektifkan proses cooperative leaning dalam pembelajaran (Aisah, S., Ashari, H., \& Akhdinirwanto, R. W. 2013: 16-18).

Media kartu dianggap sesuai dalam membantu guru untuk mencapai tujuan pembelajaran karena media kartu sangat praktis digunakan dalam kegiatan pembelajaran di kelas karena memiliki ukuran yang minimalis, desain pada kartu dapat disesuaikan dengan tujuan pembelajaran, dan mudah untuk digunakan (Sariwati, Lathifah Nur'aini; Budi Utami; \& Mohammad Masykuri. 2015: 123). Media kartu mengkonkritkan suatu konsep abstrak dan dapat mengarahkan perhatian sehingga tertuju pada satu titik fokus. Media kartu juga juga bisa meningkatkan interaksi siswa sehingga pesan dari guru dapat tersampaikan dengan baik sehingga dapat membantu meningkatkan keterampilan berpikir kritis siswa. 
Dengan berbagai kelebihan dari media kartu untuk diterapkan dalam pembelajaran di kelas sebagai sarana untuk meningkatkan keterampilan berpikir kritis siswa maka pemilihan media yang digunakan untuk meningkatkan keterampilan berpikir dalam belajar siswa adalah permainan Question Card. Permainan Question Card adalah media pembelajaran berbentuk permainan yang dilakukan secara berkelompok. Permainan ini berupa kartu soal yang menyajikan gambar maupun masalah yang berkaitan dengan kehidupan sehari-hari yang terjadi maupun yang ada di lingkungan sekitar kita. Maka untuk mengatasi permasalahan memerlukan adanya "Pengembangan Permainan Question Card Sebagai Media Pembelajaran Untuk Meningkatkan Kemampuan Berpikir Kritis Siswa".

\section{METODE}

Jenis penelitian yang digunakan dalam penelitian adalah penelitian pengembangan (Research and Development) dengan model pengembangan ADDIE (Analysis-Design-Development-Implemen tationEvaluation). Penelitian ini dilaksanakan pada pada bulan Agustus 2019. Subjek dalam penelitian ini adalah siswa SMA Negeri 1 Kota Mojokerto kelas X IPS 1 yang berjumlah 20 siswa. Hal ini sesuai dengan pendapat Sadiman bahwa uji coba yang dilakukan kepada 10-20 orang sudah mewakili target (Sadiman, A. 2014: 184). Prosedur pengembangan yang digunakan dalam penelitian ini sebagai berikut:

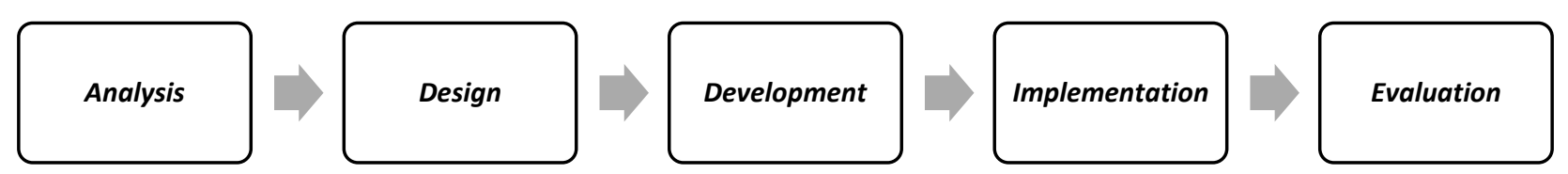

Gambar 1. Prosedur Pengembangan Model ADDIE (Mulyatiningsih, Endang. 2012: 183)

Pada prosedur pengembangan tersebut pertama dilakukan analisis masalah dan analisis kebutuhan yang akan digunakan untuk pengembangan permainan Question Card sebagai media pembelajaran serta perumusan pembelajaran yang diinginkan. Langkah ini terdiri atas dua tahap yaitu analisis kinerja dan analisis kebutuhan. Setelah itu dilakukan untuk merancang permainan Question Card sebagai media pembelajaran yang akan dikembangkan. Media permainan Question Card dibuat dengan ukuran 10x7 cm pada kertas Art Paper. Kertas ini nantinya memiliki dua sisi. Sisi depan menunjukkan tulisan Question Card dan pada sisi belakang nantinya berisi pertanyaan yang akan dijawab oleh siswa. Setiap pertanyaan dalam Question Card disesuaikan dengan SK dan KD yang diajarkan. Pada tahab pengembangan menghasilkan Permainan Question Card sebagai media pembelajaran yang layak digunakan dari hasil validasi yang dilakukan oleh ahli media dan evaluasi. Setelah produk selesai dikembangkan, produk ini diimplementasikan sesuai dengan tempat penelitian yaitu di SMA Negeri 1 Kota Mojokerto kelas X IPS 1. Pada tahap ini evaluasi dilakukan terhadap produk yang dikembangkan untuk mengukur ketercapaian tujuan pengembangan produk Question Card sesuai dengan harapan atau tidak. Tahapan ini tidak semata dilakukan pada akhir proses pengembangan melainkan dilakukan pada setiap tahap dalam proses pengembangan yang dianamakan evaluasi formatif karena bertujuan untuk kebutuhan akan revisi. Hasil evaluasi dapat dilihat melalui saran maupun masukan dari para ahli. 
Teknik pengumpulan data dalam penelitian ini adalah lembar observasi, soal tes untuk mengukur pretest dan postest, dan lembar validasi untuk soal dan media. Analisis data untuk validasi media menggunakan rumus:

$$
\text { Persentase }(\%)=\frac{\text { Jumlah Skor yang Diperoleh }}{\text { Skor Maksimal }} \times 100 \%
$$

Dari hasil perhitungan tersebut diintepretasikan dengan kriteria sebagai berikut (Riduwan. 2016: 38):

Tabel 1: Kriteria Penilaian Validasi Media

\begin{tabular}{cc}
\hline Skor & Presentase \\
\hline $0 \%-20 \%$ & Tidak Layak \\
$21 \%-40 \%$ & Kurang Layak \\
$41 \%-60 \%$ & Cukup Layak \\
$61 \%-80 \%$ & Layak \\
$81 \%-100 \%$ & Sangat Layak \\
\hline
\end{tabular}

Sedangkan analisis data untuk efektivitas permainan Question Card, dapat dilihat dari hasil pretestposttest yang dihitung dengan rumus di bawah ini:

$$
<g>=\frac{\text { Skor Posttest }- \text { Skor Pretest }}{100-\text { Skor Pretest }}
$$

Rumus tersebut digunakan untuk menentukan N-gain Score. Berdasarkan hasil yang diperoleh maka akan diintepretasikan sesuai dengan table di bawah ini (Hake. 1998: 65).

Tabel 2: Kriteria Penilaian Efektivitas Permainan Question Card

\begin{tabular}{cc}
\hline Skor Gain & Kategori \\
\hline$(<\mathrm{g}>)<0,3$ & Rendah \\
$0,3<(<\mathrm{g}>)<0,7$ & Sedang \\
$(<\mathrm{g}>)>0,7$ & Tinggi \\
\hline
\end{tabular}

\section{HASIL DAN PEMBAHASAN}

Proses Pengembangan Permainan Question Card sebagai Media Pembelajaran untuk Meningkatkan Keterampilan Berpikir Kritis Siswa

Dalam mengembangkan permainan question card ini menggunakan model ADDIE. Kelebihan model tersebut adalah sederhana dan mudah dipelajari serta strukturnya yang sistematis (Pribadi, A. Benny. 2009: 12). Prosedur pengembangan menggunakan model tersebut yaitu analisis, perencanaan, pengembangan, implementasi, dan evaluasi.

Pada prosedur pengembangan tersebut pertama dilakukan analisis. Analisis ini berisi analisis masalah dan analisis kebutuhan yang akan digunakan untuk pengembangan permainan Question Card sebagai media pembelajaran serta perumusan pembelajaran yang diinginkan. Langkah ini terdiri atas dua tahap yaitu analisis kinerja dan analisis kebutuhan. Seperti yang telah diungkapkan di awal bahwa masalah yang ada ditempat penelitian adalah tingkat berpikir kritis yang masih rendah sehingga membutuhkan media yang dapat meningkatkan tingkat berpikir kritis tersebut. 
Setelah itu dilakukan untuk merancang atau mendesain permainan Question Card sebagai media pembelajaran yang dikembangkan. Media permainan Question Card dibuat dengan ukuran 10x7 cm pada kertas Art Paper. Kertas ini nantinya memiliki dua sisi. Sisi depan menunjukkan tulisan Question Card dan pada sisi belakang nantinya berisi pertanyaan yang akan dijawab oleh siswa. Setiap pertanyaan dalam Question Card disesuaikan dengan Standar Kompetensi dan Kompetensi Dasar yang diajarkan.

Pada tahap pengembangan menghasilkan Permainan Question Card sebagai media pembelajaran yang layak digunakan dari hasil validasi yang dilakukan oleh ahli media dan evaluasi. Berdasarkan hasil validasi kelayakan Permainan Question Card untuk meningkatkan keterampilan berpikir kritis siswa oleh para ahli. Ahli evaluasi yang dilakukan oleh validator diperoleh hasil pada validator sebesar 93\% dengan kategori "sangat layak". Dari ahli media mendapatkan hasil sebesar 88,86\% dengan kategori "sangat layak".

Setelah produk selesai dikembangkan dan dinyatakan layak oleh ahli evaluasi dan ahli media, produk ini diimplementasikan sesuai dengan tempat penelitian yaitu di SMA Negeri 1 Kota Mojokerto kelas X IPS 1. Sebelum pengimplementasian media kartu tersebut, siswa diberikan soal pretest. Dan setelah selesai penggunaan media pun diberikan soal posttest. Hal tersebut berguna untuk mengetahui seberapa besar efektivitas dari media kartu. Rancangan penelitian ini adalah rancangan pretest-posttest kelompok tunggal (One Group Pretest-Posttest Design). Rancangan ini dilakukan dengan cara melakukan satu kali pengukuran di depan (pretest) sebelumm adanya perlakukan dan setelah itu dilakukan pengukuran lagi (posttest) (Juliansyah, Noor. 2013:147).

Pada tahap ini evaluasi dilakukan terhadap produk yang dikembangkan untuk mengukur ketercapaian tujuan pengembangan produk Question Card sesuai dengan harapan atau tidak. Tahapan ini tidak semata dilakukan pada akhir proses pengembangan melainkan dilakukan pada setiap tahap dalam proses pengembangan yang dinamakan evaluasi formatif karena bertujuan untuk kebutuhan akan revisi. Hasil evaluasi dapat dilihat melalui saran maupun masukan dari para ahli.

\section{Efektivitas Permainan Question Card}

Belajar merupakan proses usaha yang dilakukan seseorang untuk memperoleh suatu perubahan baik dari segi perubahan tingkah laku maupun hasil belajar (Daryanto. 2009:2). Media pembelajaran sebagai alat bantu untuk merubah perilaku dan hasil belajar tersebut (Azwar, Husnul. 2020). Dalam penelitian ini menggunakan media kartu sebab ada beberapa kelebihan dari media tersebut, yaitu: 1) media kartu bisa menampilkan komponen yang ingin dijelaskan; 2) media kartu bisa dijadikan berbagai bentuk permainan yang dapat meningkatkan kreativitas siswa di dalam kelas; dan 3) media kartu memudahkan siswa dalam belajar karena tampilan yang menarik (Khairunnisak. 2015:70). Maka untuk mengetahui efektivitas dari permainan Question Card dapat menggunakan hasil prettest-posttest. Melalui hasil prettest-posttest dapat diketahui perubahan akibat adanya suatu treatment selama proses berjalan.

Berdasarkan tingkatan taksonomi bloom pada kemampuan menghafal, menyebutkan kembali dan menerapkan informasi diklasifikasikan sebagai berpikir tingkat rendah. Sedangkan menganalisis (C4), mensintesis (C5), dan mengevaluasi (C6) diklasifikasikan sebagai berpikir tingkat tinggi (Janes, Shania Parvati; Darmawanti; dan R. Hussien Arief. 2014:3). Maka dalam penelitian ini hanya menggunakan soal prettest-posttest dengan ranah C4-C6.

Berdasarkan hasil prettest-posttest yang mencakup soal dengan ranah C4-C6 yang telah di uji cobakan pada siswa diperoleh hasil bahwa berpikir kritis siswa mengalami peningkatan. Hal ini 
juga dapat dilihat dari perhitungan $N$-gain score yang diperoleh data sebesar 0,6 yang berarti peningkatan hasil siswa berada pada kategori "sedang". Maka dapat disimpulkan bahwa media pembelajaran kartu ini efektif untuk diterapkan dalam proses pembelajaran.

Pada penelitian lain pun menyatakan bahwa penggunaan media kartu efektivitas dalam meningkatkan prestasi belajar siswa. Penerapan metode permainan kartu yang dilaksanakan guru dapat meningkatkan siswa yang berkategori tidak bisa menjadi prestasi kategori bisa (Rokhayati, A. 2010: 85-86). Permainan dapat digunakan sebagai media untuk meningkatkan motivasi siswa dalam belajar sehingga dapat meningkatkan hasil belajar (Nugroho, A. P., T. Raharjo, \& D. Wahyuningsih. 2013: 11-18).

\section{SIMPULAN}

Berdasarkan penelitian ini dapat disimpulkan bahwa permaianan Question Card sebagai media pembelajaran untuk meningkatkan keterampilan berpikir kritis siswa sangat layak digunakan sebagai alat bantu pada proses pembelajaran. Hal tersebut didapatkan dari hasil validasi yang dilakukan oleh ahli evaluasi dan ahli media yang masing-masing mendapatkan rata-rata presentase sebesar 93\% dan 88,86\% dengan kriteria sangat layak. Serta permainan Question Card sebagai media pembelajaran efektif untuk meningkatkan keterampilan berpikir kritis siswa yang ditunjukkan melalui uji $N$-Gain sebesar 0,6.

Penelitian akan lebih baik jika dilanjutkan sampai pada tahap implementasi dengan subjek penelitian yang lebih luas lagi. Permainan Question Card sebagai media pembelajaran untuk meningkatkan keterampilan berpikir kritis siswa sudah sangat layak digunakan baik dari segi soal maupun media dengan presentase sebesar $93 \%$ dan $88,86 \%$. Menurut ahli evaluasi dan media hal ini kurang maksimal oleh karenanya pada bagian soal masih terdapat beberapa soal yang masih bisa diringkas lagi sehingga soal menjadi lebih jelas dan pada media untuk warna media masih bisa didesain lebih menarik lagi.

\section{DAFTAR PUSTAKA}

Aisah, S., Ashari, H., \& Akhdinirwanto, R. W. (2013). Penggunaan Model Pembelajaran Cooperative Learning Tipe Think Pair Square Berbantuan Kartu Soal untuk Meningkatkan Aktivitas Belajar Siswa Kelas VII B SMP Negeri 5 Purworejo Persentase Rata-Rata Aktivitas. Radiasi, 3(1), 16-18.

Arends, R. (2008). Learning to Teach (Belajar untuk Mengajar). Yogyakarta: Pustaka Belajar.

Arsyad, A. (2013). Media Pembelajaran. Jakarta: PT RajaGrafindo Persada.

Azwar, Husnul. (2020). Pentingnya Penggunaan Media Pembelajaran Untuk Meningkatkan Prestasi Belajar Siswa Min 7 Pessel. Diakses pada https://sumbar.kemenag.go.id/v2/post/54610/pentingnya-penggunaan-media-pembelajaranuntuk-meningkatkan-prestasi-belajar-siswa-min-7-pessel.

Daryanto. (2009). Panduan Proses Pembelajaran Kreatif \& Inovatif. Jakarta: AV Publisher.

Depdiknas. (2003). Undang-undang RI Nomor 20 Tahun 2003 tentang Sistem Pendidikan Nasional. Jakarta: Departemen Pendidikan Nasional.

Hadikusuma, Donie \& Wiyatmo, Yusman. (2019) Pengembangan Variative Question Cards Dengan Model Pembelajaran Stad (Student Team Achievement Divisions) Guna Meningkatkan Minat Dan Hasil Belajar Fisika Pada Materi Gerak Melingkar. Yogyakarta: Univeritas Negeri Yogyakarta. 
Hake, R. R. (1998). Interactive-Engagement versus Traditional Methods: A Six-Thousand-Student Survey of Mechanics Test Data for Introductory Physics Courses. American Journal of Physics, 66(1), 64-74.

Janes, Shania Parvati; Darmawanti; dan R. Hussien Arief. (2014). Kemampuan Berpikir Kritis Siswa SMA dalam Menyelesaikan Soal Uji Kompetensi Tertulis (UKT) pada Olimpiade Sains Biologi SMPSMA Se-Riau 2014. Riau: Universitas Riau.

Juliansyah, Noor. (2013). Metodologi Penelitian. Jakarta: Kencana Prenada Media Group.

Khairunnisak. (2015). Penggunaan Media Kartu sebagai Strategi dalam Pembelajaran Membaca Permulaan: Studi Kasus di Madrasah Ibtidaiyah Negeri Rukoh, Banda Aceh. Jurnal Pencerahan, 9(2), 66-82.

Nugroho, A. P., T. Raharjo, \& D. Wahyuningsih. (2013). Pengembangan Media Pembelajaran Fisika Menggunakan Permainan Ular Tangga Ditinjau dari Motivasi Belajar Siswa Kelas VIII Materi Gaya. Jurnal Materi dan Pembelajaran Fisika, 1(1), 11-18.

Mulyatiningsih, Endang. (2012). Metode Penelitian Terapan Bidang Pendidikan. Bandung: Alfabeta.

Riduwan. (2003). Dasar-Dasar Statistika. Bandung: Alfabeta.

Rokhayati, A. (2010). Meningkatkan Kemampuan Membaca pada Mata Pelajaran Bahasa Indonesia melalui Permainan Kartu Kalimat. Jurnal Saung Guru. 1(2), 85-86.

Sadiman, A. (2014). Media Pendidikan Pengertian, Pengembangan dan Pemanfaatannya. Jakarta: PT RajaGrafindo Persada.

Sanjaya, Wina. (2008). Perencanaan Dan Desain Sistem Pembelajaran. Jakarta: Kencana.

Sariwati, Lathifah Nur'aini; Budi Utami; \& Mohammad Masykuri. (2015). Upaya Meningkatkan Kemampuan Berpikir Kritis dan Prestasi Belajar Siswa dengan Model Problem Solving Dilengkapi Media Kartu Kelas X MIA 3 Semester II SMA Al Islam 1 Surakarta Tahun Pelajaran 2014/2015. Jurnal Pendidikan Kimia 4(4), 123-131.

Pribadi, A. Benny. (2009). Model Desain Sistem Pembelajaran. Jakarta: Dian Rakyat.

Zaki, Faiz. (2018). Pentingnya Berpikir Kritis, 6 Manfaat Ini Pasti Didapatkan. Diakses pada https://www.idntimes.com/life/inspiration/faiz-zaki/pentingnya-berpikir-kritis-c1c2/6. 